американских тюремных и связанных с ними системах; непропорционально много приговоров выносится чернокожим. Эта статья основана на деонтологической этике, согласно которой права человека являются натуральным обязательством, которое нельзя исключать при формировании государственной политики или осуществлении правосудия. Также предполагается, что в рамках реформ существуют потенциальные возможности для революций. Актуальные вопросы, поднятые в этом исследовании, касаются условий для оздоровления ситуации в рамках систем, являющихся расистскими по своей структуре. Достаточно ли одних реформ или есть повод для революционных действий? Министерство юстиции начало расследование тревожной череды смертей в Департаменте исполнения наказаний штата Миссисипи. В данной работе будут рассмотрены потенциальные изменения государственной политики, а также реакция общества на них.

Ключевые слова: раса; этичность; государственная политика; жизни чернокожих; американское правительство; расследование; революция.

Дата поступления: 02.03.2020

УДК 340.1

DOI: 10.33184/pravgos-2020.3.2

\title{
PSYCHOLOGY OF INTEREST IN SOCIAL AND LEGAL RELATIONS
}

\section{KHALIKOV Aslyam Nailevich}

Doctor of Law, Professor, Professor of the Institute of Law of the Federal State Budgetary Educational Institution of Higher Education "Bashkir State University", Ufa, Russia.E-mail: an010@yandex.ru

The psychology of the category of interest has a multifaceted character, which is the semantic line of human life. At the same time, interest begins with individual's psychology, then there is a transition to interests in social and legal relations, and then the interest again turns into personal motivation, but already in a social environment. The main psychological feature of interest is its emotional component, without which the interest loses its subjective meaning. It is reflected in legal relations between the state and society. Purpose: to consider the concept and characteristics of interest in social and legal relations. Methods: empirical methods of comparison, description, interpretation; theoretical methods of formal and dialectical logic. Results: the author comes to the conclusion that the construction of a person's interest at the present time does not come from two 
components - individual and social, but from three, which will certainly include the third component as interests at the level of international relations.

Key words: interest; motivation; society; cognition; needs; person; emotions.

The category of interest in psychology is significant in different aspects: cognitive, emotional, interpersonal, educational, semantic, etc. Interest itself is often differentiated by public and personal interest, and that goes to the peculiarities of its studies in the field of social and personal psychology. Of course, the different orientations of interests of the society on the one hand and the individual on the other hand often do not coincide, shifting to internal and social conflicts, which begin with domestic situations and can lead to sociopolitical events. At the same time, the essence of interest as the demonstration of mind and emotions is expressed primarily through the individual, his subjective understanding of the objects of interest. In this respect, notion of the personal interest is dominant followed by the social interest which is again transformed into the individual interest in a society and therefore into the optimal balance between individual and public interests.

To a certain extent, personal and public interest is connected with an understanding of the interest, both internal and external. A person's inner interest is an interest in the processes within an individual's body, related to his psychology and physiology, in other words, when the subject is firstly interested in his own state processes which are clearly aimed at satisfying his inwardness. External interest is the interest of a person in an object or activity, the source is outside this person, outside his psychology or the processes occurring in the body [9, p. 157]. At the same time, the realization of the external interest in most cases follows the satisfaction of the internal interest; however, for this purpose external factors of interest are often addressed because they being of more important character influence internal interests. So, we see an ever-changing place of interests in the life of an individual with respect to interests of a society and social institutions when individual (internal) interests change into public (external) though social interests can exist only while they are accepted by the particular subjects satisfying their internal interests. In this sense, K. Helvetius, speaking of interest as a major factor in the progressive movement of people, their feelings and thoughts, wrote, that if the physical world is subordinated to the law of motion, then the spiritual world is no less subject to the law of interest. On earth interest is an omnipotent wizard, changing the look of all creatures. Interest is the beginning of all our thoughts and all our actions [3, p. 146-200].

Considering the psychological content of interest from a philosophical point of view, it should be noted that interest is based on the orientation of the will and action towards a purpose, achievement of which is regarded as subjectively important for it satisfies the need that is interpreted as fundamental. In practical philosophy difference between particular interests, universal and potentially 
universal, is of great importance. Potentially universal interests are those found in all human beings and are characterized by the fact that the consequences of their realization can be freely accepted by all affected. If this condition is met, this refers to the interest of all and, if not it is a case of particular (private) ones.

In its turn, I. Kant determined that every ability of the soul can be attributed interest, a principle that contains the condition that only the use of this ability can be successful. Reason as the ability to give principles defines the interest of all emotional forces as well as its own interest. The interest of its speculative application lies in the knowledge of the object up to the highest apriori principles; the interest of its practical application is in the determination of the will for the final and complete purpose. What is required for the possibility of the use of reason in general, specifically that its principles and assertions are not contradictory, is not part of its interest; it is a condition for the possession of reason at all; only the expansion of the mind, and not just its relevance to itself we take as its interest [7, p. 517].

So, what does the category of interest mean in the life of an individual and a society in whole?

Studying a large body of literature on the content of interest, we have more than once met the opinion that it is definitely impossible to understand the category of interest and moreover, the frequently considered category is at the level of intuitive or individual understanding. For instance, the psychologist A. Reber writes that the meaning of the term «interest» is very loose, and at the same time this term was used for defining the following notions: attention, curiosity, motivation, concentration, concerns, purposefulness, awareness and desire. A majority of authors just follow their gut while using it; it is difficult to use it incorrectly [11, p.321].

In its turn, T.V. Shorokhova, also noting that there is still no universal definition of the concept of interest, divides its expression into several aspects: 1) axiological; 2) cognitive; 3) in the meaning of «benefit», "good», "profit»; 4) emotional-cognitive; 5) interest as a relationship; 7) need-motivational [13]. In this case, as we can see, a broad understanding of interest and necessarily intersecting its directions with each other in the view of the ambiguous psychological treatment of the concept take place as well.

A diverse understanding of the interest category is often seen in comparison with similar concepts such as needs, motivations, wishes. Of course, given notions are connected with interest to some extent because this refers to active orientation of the human activity towards the specific object (objects). But the importance of interest versus, say, needs is much more important as it is seen in a deeper sense which should be defended and actively pursued. S. L. Rubinstein defined interest as a tendency or orientation of the individual, consisting in concentrating his thoughts on a certain object. With this in mind, interest as focus of intentions differs significantly from the focus of wishes in which need is prima- 
ry. Interest affects attention, thoughts, intentions; need has a significant impact on attraction, wishes, will [12, p.525]. For instance, in certain circumstances, needs or wishes may be limited or even eliminated. It is much more difficult to perform in regard to personal interests as the purport of existence which may be linked with his main values of existence such as physical life, health, family, destiny, etc. Differentiating between needs and interests E.P. Ilyin writes that for a person object or activity becomes important when there is a need so the emphasis in the understanding the need-interest goes to the purpose sort of «marking» interest shows to which it displays itself. Interest can't exist without an address though it may not be specific; it represents a broader field of activity or a range of subjects. Therefore, the view of some psychologists that the interest is not equal to the need is legitimate [6, p.168].

In general, the content of interest can be strictly divided into three parts each of which is an objective existence creating a vital need for the individual in the system of social and legal relations:

1) personal and individual interests focused on a particular object according to its attractiveness (parental or marital love, friendship) or necessity (legal categories of freedom, justice, equality, property);

2) social or socio-economic interests of an individual which occur only in relation to the interests of other socio-economic and legal entities (state, society, personnel, etc.);

3) cognitive interests in view of the rationality of the human being and the constant quest to learn the outside world which in itself constitutes an important, if not a major, factor in the development of humankind [1, p. 127-128].

The totality of an individual's interests creates an entire system formation, where each interest or interests themselves are in relation to each other, complementing and broadening the essence of its content. For example, material interests of any person may be achieved only by realizing his cognitive interests, in particular, striving for study, development of professional skills, discoveries in science and technology. At the same time, cognitive interest cannot be separated from the spiritual interests of a person in the cultural development, treatment of other people, interest to different beliefs and religion in general. The development of spiritual interests leads to the fact that the subject perceives his family interests and the interests of close people in unity with his own interests and sometimes even more valuable than his own. In a certain way, a reasonably constructed system of interests in a person's life, together with overcoming difficulties and obstacles in the observance or struggle for interests, allows to maintain its self (its identity) in all situations and to develop in a true human direction, while preserving the basic values of the world - freedom, equality, justice. Notably, these values are subsequently transformed into legal ones with the appropriate enforcement mechanisms in respect to the citizens of the state. 
On the mechanism of interest formation V.V. Nikandrov writes that initially interest can even display itself by means of external attractiveness, and only after that its life purpose is realized [10, p.763]. Thus, the content of interest derives from the positive exterior features of an object that are consciously, and sometimes subconsciously, accepted by the person in his or her senses and perceptions. This is followed by the process of understanding and cognizability of an object, it itself will be the subject of the cognitive individual interest. After that, the presence of interest becomes the necessity of its existence for the person, transforming into the basic principles of the meaning of the human life in relation to the external world. In system unity, different interests in a person's life may still be competing in their importance for his or her future life, but interests themselves constitute the essence of a person's physical, social and legal existence, without the satisfaction of which it loses itself and its place in the social environment and in the world.

At the same time, almost all the psychologists agree that the main element in the category of interest is its emotional appeal. As C. Izard says, one cannot overestimate the importance of the emotion of interest - stimulation for individual development, personal becoming and socialization of a person. Having this in mind, any fundamental emotion performs a social function. The human being is first and foremost a social being whose well-being and civilization require a certain degree of social organization and order; it can therefore be said that every human being has some social interest based on emotion [5, p.124-133].

In a normal society and a state, the category of interest is dynamic, that is, the striving for constant development, change, transition from elementary or low interests to higher, qualitative interests. In this connection, the satisfaction of some interests and the transition to others undoubtedly develop a person who, after a positive result, always pursues or, in any case, displays the desire (attention) for other, better interests. Though this does not, of course, exclude the attractiveness of an object or activity of dominant interest. In some extent, interest development resembles the hierarchy of needs of A. Maslow from the basic or lower (food, sex, safety) to the higher ones (self-actualization in a society, state service, aesthetic needs, etc.) [8].

As it was mentioned in the article, personal interests are not separable from the public ones in the social environment in which the individual is located; as a result, their relationship always involves a process of evaluation of some with the evaluation of others, while maintaining a certain balance. Of course, in some certain situations, personal or social interest may be dominant though driving it to extremes has only negative consequences. Let us assume that the display of an exceptionally personal interest may lead to deviant behaviour, including criminal offences, which in some cases is an extreme degree of self-interest. However, the existence of exceptionally social interests, with unreasonable denigration of personal ones, may lead to the same negative manife- 
stations against particular citizens, their health, life and property, assuming that only the interests of the state are called upon, completely ignoring the personal one. Speaking of the necessity to unite personal and social interests B. Yak states that human society doesn't disintegrate due to combination of personal interests, norms of justice and social friendship. In other words, this combination with one another has three reasons: calculations of what will serve our own interests, beliefs about what we owe each other, and feelings of special care for the well-being of the people who we have something in common with [14, p.95].

In order to develop interests, there must be an appropriate environment for the individual to develop his interests or individual interests must be optimally related to the social interests. In addition to that, social interests, as opposed to the individual ones, are to some extent transformed into the level of the general needs which may not meet the individual needs, and sometimes even contradict them. This contraposition of the individual and public interests has always been a problem in a society and states, where the incomparability of collective and personal interests has escalated to riots, revolutions and civil wars. Although it was essentially a clash of deeply hidden personal interests between an individual as a leader or a group of individuals who took the responsibility (sometimes irresponsibility) to speak on behalf of the people or a part of a social group within a state.

Hence, understanding interest as an objective or subjective category in relation to the individual is a challenging issue. If we have stated that the interest surely relies on the emotional attitude towards it, then in this case we speak about a subjective direction of the interest development. Moreover, a person being in a fit of temper or rage may act at first glance to satisfy only his own interests (killing the offender), but in reality he will only worsen his situation and come out against his true interests. Consequently, the reasonable combination of personal interests with those of other people, a society and even a state leads to the objectification of the interest, to the understanding of its necessity and verity in the context of one's self and the outside world. A.G. Zdravomyslov writes that the interest is considered as a dialectical unity of objective and subjective. The balance between objective and subjective in the interest is double-natured. On the one hand, it is the transition of the objective into the subjective because any interest has a definite basis in the surrounding circumstances. On the other hand, it is the transition of the subjective into the objective because the interest is the motive of the activity which transforms subjective goals, desires, intentions, etc into reality. Double-natured understanding of the interest - objective and subjective - is its main difficulty [4, p. 6-7].

In general, the interest is the result of the development of the objective reality at a certain time and in a certain localization, regardless of whether it is seen in the individual or in the public sense. While we may speak of the typical ba- 
sic and legal values of an individual and a society such as freedom, equality, justice and property, the form of displaying an interest will always differ depending on the historical time and place of the state in question. It is another matter that the world development of practically all the states is now being equalized by world or global processes in the form of transport possibilities, the Internet, open borders, etc. This leads to the emergence and development of the unity of social and legal interests in the world community, which also affects the unity of individual interests, social and even state interests. Thus, these objective processes influence the standard features of the psychology of interest of any individual, and especially of young people, who are most open to new ideas and directions that shape their interests in the context of globalization. As a result, the construction of human interest is currently based not on the two components - individual and public, but on three, which will necessarily include the third component as interests at the level of international (not inter-state!) relations.

\section{References}

1. Antsupov A.Ya., Shipilov A.I. Conflict Dictionary, St. Petersburg, 2006.

2. Brockhaus. Philosophy: concepts, thinkers, concepts, edited by T. Uvarov, trans. and ed. text: E.V. Alymova et al., St. Petersburg, Amphora, RKhGA, 2010.

3. Helvetius K.A. On the mind, Works, In 2 volumes, T. 1, Moscow, Thought, 1974.

4. Zdravomyslov A.G. The problem of interest in sociological theory, Leningrad, Leningrad State University, 1964.

5. Izard K.E. The Psychology of Emotions, St. Petersburg, Peter, 2008.

6. Ilyin E.P. Motives and motivation, St. Petersburg, Peter, 2002.

7. Kant. I. Critique of practical reason, Works, In 8 volumes, V. 4, Prolegomena. Fundamentals of the metaphysics of morals. Metaphysical principles of natural science. Criticism of practical reason, under total. ed. prof. A.V. Gulygi. Moscow, CHORO, 1994.

8. Maslow A.G. Motivation and personality, trans. from English. A.M. Tatlybaev. St. Petersburg, Eurasia, 1999.

9. Nemov R.S. Psychological Dictionary, Moscow, Humanities. ed. center VLADOS, 2007.

10. Nikandrov V.V. Psychology, textbook, Moscow, Prospect, 2007.

11. Reber A. Big explanatory psychological dictionary, In 2 volumes, T. 1, Moscow, Veche, AST, 2001.

12. Rubinstein S.L. S. Fundamentals of General Psychology, Moscow, 2008.

13. Shorohova T.V. The problem of defining the category of "interest" in modern domestic psychology and pedagogy, Internet journal Eidos. 
14. Yak B. Nationalism and moral psychology of the community, Moscow, Gaidar Institute, 2017.

Received: 22.08.2020

DOI: $10.33184 /$ pravgos-2020.3.2

\section{ПСИХОЛОГИЯ ИНТЕРЕСА В СОЦИАЛЬНЫХ И ПРАВОВЫХ ОТНОШЕНИЯХ}

\section{ХАЛИКОВ Аслям Наилевич}

доктор юридических наук, профессор, профессор кафедры криминалистики Института права ФГБОУ ВО «Башкирский государственный университет», г. Уфа, Россия. E-mail: an010@yandex.ru

Психология категории интереса имеет многоаспектный характер, являющийся смысловой линией человеческой жизни. В то же время интерес начинается с психологии отдельного индивида, затем следует переход на интересы в социальных и правовых отношениях, а затем интерес вновь переходит в личностную мотивацию, но уже в условиях социального окружения. Основной психологической особенностью интереса является его эмоциональная составляющая, без которой интерес теряет свой субъективный смысл. Это имеет отражение и в правовых отношениях государства и общества. Цель: рассмотреть понятие и характеристику интереса в социальных и правовых отношениях. Методы: эмпирические методы сравнения, описания, интерпретации; теоретические методы формальной и диалектической логики. Результаты: автор приходит к выводу, что конструирование интереса у человека в настоящее время исходит не из двух составляющих - индивидуального и общественного, а из трех, куда непременно будет все больше входить и третья составляющая как интересы на уровне международных отношений.

Ключевые слова: интерес; мотивация; общество; познание; потребности; человек; эмоции.

Дата поступления: 22.08.2020 